\title{
Associations among body composition, inflammatory profile and disease extent in ulcerative colitis patients
}

\author{
Ana Paula Signori Urbano ${ }^{1}$, Ligia Yukie Sassaki ${ }^{1}$, Mariana de Souza Dorna ${ }^{1}$, Paula Torres Presti ${ }^{1}$, \\ Maria Antonieta de Barros leite Carvalhaes ${ }^{2}$, Ligia Araújo MartinI³ ${ }^{3}$ Ana lucia Anjos Ferreira ${ }^{1 *}$ [0 \\ ${ }^{1}$ Department of Internal Medicine, Universidade Estadual Paulista (Unesp), Faculdade de Medicina, Botucatu, SP, Brazil \\ ${ }^{2}$ Nursing Department, Universidade Estadual Paulista (Unesp), Faculdade de Medicina, Botucatu, SP, Brazil \\ ${ }^{3}$ Associate Professor, Department of Nutrition, Faculdade de Saúde Pública, Universidade de São Paulo (FSP-USP), São Paulo, SP, Brazil
}

Study conducted at Universidade Estadual Paulista (Unesp), Faculdade de Medicina, Botucatu, SP, Brazil

Article received: $7 / 24 / 2017$ Accepted for publication: $8 / 6 / 2017$

*Correspondence:

Departamento de Clínica Médica, Faculdade de Medicina de Botucatu, Unesp Address: Distrito de Rubião Junior, $\mathrm{s} / \mathrm{n}$ Botucatu, SP - Brasil Postal code: 18618-970 ferreira@fmb.unesp.br

\section{SUMMARY}

Objective: The aim of our study was to assess body composition status and its association with inflammatory profile and extent of intestinal damage in ulcerative colitis patients during clinical remission.

Method: This is a cross-sectional study in which body composition data (phase angle [PhA], fat mass [FM], triceps skin fold thickness [TSFt], mid-arm circumference $[\mathrm{MAC}]$, mid-arm muscle circumference [MAMC], adductor pollicis muscle thickness $[\mathrm{APMt}]$ ), inflammatory profile (C-reactive protein [CRP], $\alpha 1$-acid glycoprotein, erythrocyte sedimentation rate [ESR]) and disease extent were recorded.

Results: The mean age of the 59 patients was 48.1 years; $53.3 \%$ were women. Most patients were in clinical remission (94.9\%) and 3.4\% was malnourished according to body mass index. $\mathrm{PhA}$ was inversely correlated with inflammatory markers such as CRP $(\mathrm{R}=-0.59 ; \mathrm{p}<0.001)$ and $\mathrm{ESR}(\mathrm{R}=-0.46 ; \mathrm{p}<0.001)$ and directly correlated with lean mass: MAMC $(\mathrm{R}=0.31 ; \mathrm{p}=0.01)$ and $\mathrm{APMt}(\mathrm{R}=0.47 ; \mathrm{p}<0.001)$. Lean mass was inversely correlated with non-specific inflammation marker (APMt vs. ESR) and directly correlated with hemoglobin values (MAMC vs. hemoglobin). Logistic regression analysis revealed that body cell mass was associated with disease extent (OR 0.92; 95CI 0.87-0.97; $\mathrm{p}<0.01$ ).

Conclusion: $\mathrm{PhA}$ was inversely correlated with inflammatory markers and directly correlated with lean mass. Acute inflammatory markers were correlated with disease extent. Body cell mass was associated with disease extent.

Keywords: Body Composition. Ulcerative Colitis. C-Reactive Protein. Biomarkers. Severity of Illness Index.

\section{INTRODUCTION}

Ulcerative colitis (UC) is one of the main forms of inflammatory bowel disease (IBD) characterized by chronic inflammation of the gastrointestinal tract. It represents an important public health problem, for it begins in young adulthood, lasts throughout life and may affect education, working ability, long-term productivity, social life and the quality of life of the patients. ${ }^{1}$ Studies showed increased incidence of IBD in developing countries, including Brazil..$^{2-6}$ Although its pathogenesis remains unknown, genetic, immunological and environmental factors have been associated with UC.,
Follow-up of inflammatory biomarkers has been considered useful to measure disease activity and severity. ${ }^{9,10}$ It is also known that nutritional status has strong correlation with disease severity. ${ }^{11}$ On the other hand, the nutritional status of patients during clinical remission still remains to be clarified. ${ }^{12}$ It is plausible that the body composition status, inflammatory profile and disease severity are associated with active disease. However, to the best of our knowledge, that association is unknown during disease remission. Therefore, the purpose of our study was to assess body composition status and its association with inflammatory profile and extent of intes- 
tinal damage in UC patients during clinical remission or mild disease activity.

\section{Method}

Patients

A total of 61 UC patients treated at the IBD outpatient care of our hospital from March 2009 to March 2010 were prospectively evaluated. Inclusion criteria were patients of both genders in clinical remission or with mild disease activity according to clinical and laboratory findings. Exclusion criteria were individuals with moderate or severe disease, those who had partial or total resection of the colon and those with severe disease that led to decreased food intake compared with the usual food intake. Disease activity was assessed according to the Truelove and Witts criteria. ${ }^{13}$ Patients were evaluated according to the clinical course of disease, body composition and inflammatory profile. To determine disease extent (distal colitis, leftsided colitis or pancolitis), data at diagnostic were used. Time of diagnosis, time of disease remission and drugs being used were also recorded. The study was approved by the Research Ethics Committee of the São Paulo State University (Unesp), Medical School, Botucatu (protocol \#3190/2009). An informed consent form was signed by all participants.

\section{Body composition assessment}

Body composition was evaluated using anthropometry and bioelectrical impedance analysis (BIA).

\section{Anthropometric measurements}

Body height and weight were measured and used to calculate body mass index (BMI). ${ }^{14}$ Mid-arm circumference (MAC) was measured using a measuring tape, as previously described. ${ }^{15}$ Triceps skin fold thickness (TSFt) was measured according to previous standardization. ${ }^{16}$ Midarm circumference (MAC) was measured at the midpoint between the acromioclavicular joint and olecranon process. Mid-arm muscle circumference (MAMC) was obtained from the following respective formulas: MAMC $=$ MAC(pxTSFt). ${ }^{17}$ The adductor pollicis muscle thickness (APMt) was assessed as previous study. ${ }^{18}$ Nutritional status was classified using BMI, MAC and TSFt variables. The stratification for BMI $\left(\mathrm{kg} / \mathrm{m}^{2}\right)$ depended on the age. Subjects $<60$ years: malnutrition $(<18.4)$, eutrophic $(18.5-24.9)$, overweight (25.0-29.9), obese ( $>30) \cdot{ }^{14}$ Subjects $\geq 60$ years: low weight ( $\leq 22.0)$, eutrophic (22.1-26.9) and overweight $(\geq 27.0) .{ }^{19}$ The classification for MAC and TSFt occurred according to percentiles as follow: malnourished $\left(<10^{\text {th }}\right)$, eutrophic $\left(10^{\text {th }}-90^{\text {th }}\right)$, obese $\left(>90^{\text {th }}\right) .{ }^{20}$
Bioelectrical impedance analysis (BIA)

BIA was performed using a tetrapolar single-frequency apparatus $(50 \mathrm{kHz}$ and $0.8 \mathrm{~mA}$; Biodynamic-450, Biodynamics Corporation, USA) applied to the skin using adhesive electrodes. Phase angle $(\mathrm{PhA})$ derived from the BIA was determined as previously described ${ }^{21}$ and its values were calculated as follows: $\mathrm{PhA}=$ arc tangent reactance/ resistance ${ }^{*}\left(180^{\circ} / \pi\right)$. Body cell mass $(\mathrm{BCM})$ and fat mass (FM) were recorded according to the parameters given by the device. Measurements were taken in patients after 12-hour overnight fast, voiding the urine bladder and laying in the supine position for 15 minutes. ${ }^{12}$

\section{Inflammatory profile}

A venous blood sample $(50 \mathrm{~mL})$ was obtained from patients after overnight fasting and analyzed in the routine laboratory for hemoglobin, C-reactive protein (CRP), $\alpha 1$-acid glycoprotein and erythrocyte sedimentation rate (ESR). All determinations were made by means of standardized laboratory techniques.

\section{Statistical analysis}

Statistical analysis was performed using SAS, version 9.2.3 (SAS Institute Inc., Cary, NC, USA). p $<0.05$ was considered statistically significant. Results were expressed in medians (percentile range $25-75^{\text {th }}$ ). The significance of differences among groups was calculated by Kruskal-Wallis's test complemented by Tukey's test. For correlation analysis, Pearson correlations were computed in each case. In order to verify the possible association between disease extent and body composition variables, logistic regression was used for ordinal data with adjustment for proportional hazards model.

\section{Results}

Sixty-one (61) consecutive patients were evaluated and two patients were excluded (one pregnancy, one non-reliable data). A total of 59 patients ( 32 women and 27 men; $48.14 \pm 13.9$ years) were studied. Twenty-six $(26,44.1 \%)$ patients had distal colitis, 11 (18.6\%) had left-sided colitis and $22(37.3 \%)$ had pancolitis. The time (median [percentile range $\left.25^{\text {th }}-75^{\text {th }}\right]$ months) of diagnose among the three types of extent of intestinal injury was similar $(\mathrm{p}=0.13)$ (distal colitis: 114.0 [60.0-144.0] months, left-sided colitis: 120.0 [48.0-156.0] months and pancolitis: 96.0 [48.0-132.0] months). Most patients (94.9\%; $\mathrm{n}=56$ ) were in clinical remission ( $\geq 6$ months: $\mathrm{n}=43$; $<6$ months: $\mathrm{n}=13$ ) and only three (5.1\%) displayed mild disease activity. The longest remission time (months) was found in patients with distal colitis (distal colitis: 24.0 [12.0-72.0] > pancolitis: 12.00 
[4.0-24.0] > left-sided colitis: 3.00 [0.5-18.0]; $\mathrm{p}<0.001$, by Kruskal-Wallis's test complemented by Tukey's test). Fifty-three (53, 89.8\%) patients used daily medication, most commonly aminosalicylates (mesalamine and sulfasalazine), and five (8.5\%) used low-dose corticosteroids. Most patients were classified as eutrophic according to MAC (84.70\%) and TSFt (83\%). Few (3.40\%) patients were stratified as malnourished, $40.60 \%$ as eutrophic and $56 \%$ as overweigh/obese, according to BMI.

The values (median [percentile range $25^{\text {th }}-75^{\text {th }}$ ) of hemoglobin (13.85 [13.10-14.90] g/dL), albumin (4.40 [3.90-4.50] g/dL), CRP (5.00 [3.00-11.00] mg/L), $\alpha 1$-acid glycoprotein $(103.00$ [79.00-124.00] mg/dL) and ESR (21.00 [14.00-39.00] $\left.\mathrm{mm} \mathrm{h}^{-1}\right)$ were normal according to reference ranges.

Phase angle was directly correlated with hemoglobin values and inversely correlated with acute (CRP) and nonspecific (ESR) inflammatory markers (Table 1). Phase angle also was positively correlated with lean mass indicators (MAMC and APMt) (Figures $1 \mathrm{~A}$ and $1 \mathrm{~B}$ ). Fat mass (FM and TSFt) was directly correlated with acute-phase protein ( $\alpha 1$-acid glycoprotein), while lean mass (APMt) was inversely correlated with non-specific inflammation marker (ESR). Additionally, lean mass (MAMC) also was directly correlated with hemoglobin values (Table 1).

Furthermore, acute inflammatory markers were associated with duration of clinical remission and extension of disease. Alfa-1-acid glycoprotein was inversely correlated with remission time $(\mathrm{R}=-0.23 ; \mathrm{p}<0.05)$. Subjects with more extensive injury (pancolitis) displayed higher CRP levels (median [percentile range $25^{\text {th }}-75^{\text {th }}$ ] mg/dL) than those with less extensive lesion (distal colitis) (0.8 [0.4-1.9] $>0.3[0.2-0.6] ; \mathrm{p}=0.02$, by Kruskal-Wallis's test complemented by Tukey's test).

Logistic regression was used to assess possible association between disease extent and body composition variables. After adjustment for energy, gender, age and CRP, logistic regression analysis showed that BCM was associated with disease extent. There was no association with other parameters (Table 2).

\section{Discussion}

The results revealed that body composition parameters, inflammatory markers and disease extent were associated in UC patients. Phase angle was inversely correlated with inflammatory markers such as CRP and ERS and directly correlated with hemoglobin values and lean mass indicators (MAMC and APMt). Logistic regression analysis revealed that body cell mass was associated with disease extent. This is the first time that association among body composition, inflammatory profile and disease extent was studied in UC patients in clinical remission.

Ulcerative colitis is frequently associated with changes in nutritional status. This may vary from only mild alterations in trace elements to severe malnutrition with great weight loss due to the involvement of the gastroin-

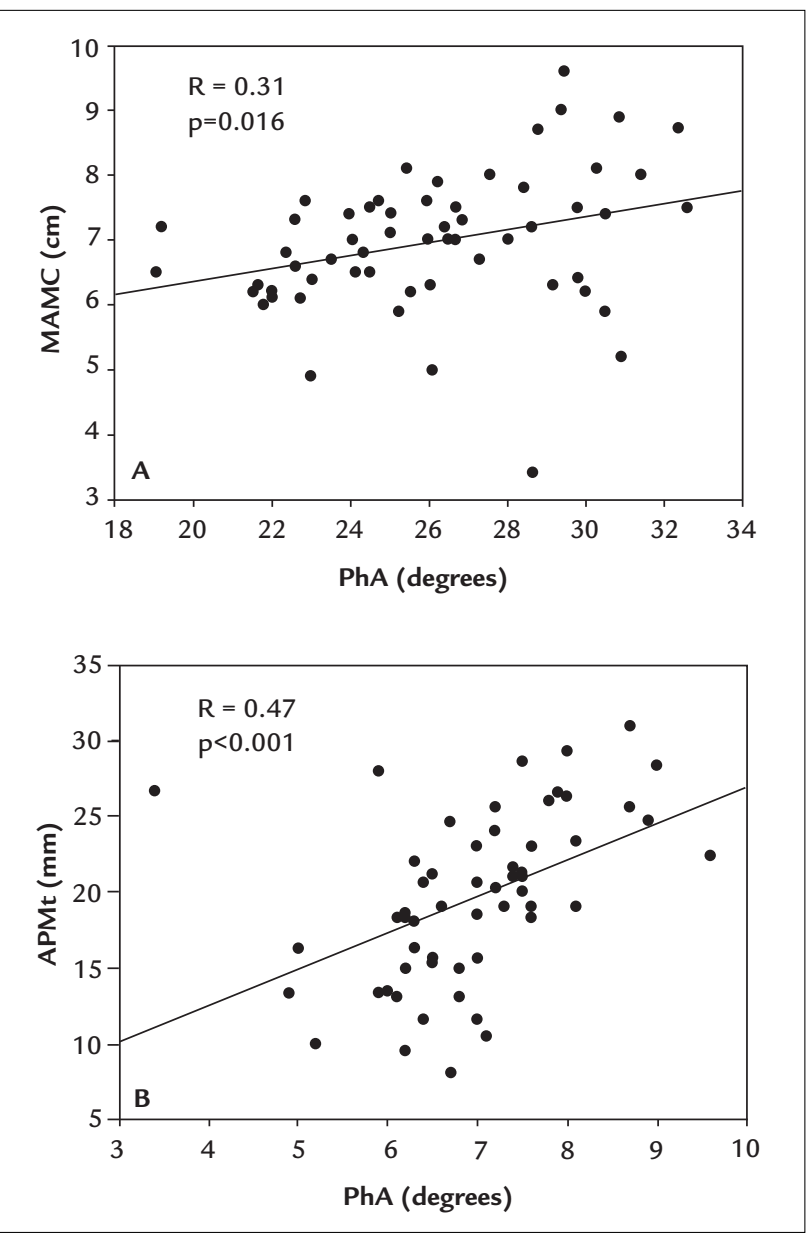

FIGURE 1 Pearson's correlation between phase angle and anthropometric variables. A. PhA versus MAMC. B. PhA versus APMt. R: Pearson's correlation coefficient; MAMC: mid-arm muscle circumference; APMt: adductor pollicis muscle thickness; PhA: phase angle.

TABLE 1 Correlation between biochemical and body composition parameters in patients with ulcerative colitis.

\begin{tabular}{llllllll} 
& BMI & FM & TSFt & MAC & MAMC APMt & PhA \\
\hline $\mathrm{Hb}$ & 0.44 & 0.01 & -0.10 & 0.21 & $0.30^{3}$ & 0.23 & $0.49^{1}$ \\
\hline $\mathrm{CRP}$ & -0.008 & 0.01 & 0.08 & 0.90 & -0.09 & -0.16 & $-0.59^{1}$ \\
\hline $\mathrm{ESR}$ & 0.02 & 0.12 & 0.07 & 0.49 & -0.18 & $-0.40^{2}$ & $-0.46^{1}$ \\
\hline$\alpha 1-\mathrm{AG}$ & $0.36^{1}$ & $0.26^{2}$ & $0.29^{2}$ & $0.25^{3}$ & 0.03 & -0.02 & $-0.23^{3}$ \\
\hline
\end{tabular}

Values represent Pearson's correlation coefficient (R); $\mathrm{Hb}$ : hemoglobin; CRP: C-reactive protein; ESR: erythrocyte sedimentation rate; $\alpha 1-\mathrm{AG}$ : $\alpha 1$-acid glycoprotein; BMI: body mass index; FM: fat mass; TSFt: triceps skin fold thickness; MAC: mid-arm circumference; MAMC: middex; FM: fat mass; TSFt: triceps skin fold thickness; MAC: mid-arm circumference; MAMC: mid-
-arm muscle circumference; APMt: adductor pollicis muscle thickness; PhA: phase angle; superscript numbers represent statistical significance: ${ }^{1} p<0.001 ;{ }^{2} p<0.01 ;{ }^{3} p<0.05$. 
TABLE 2 Association between body composition variables and disease extent in patients with ulcerative colitis.

\begin{tabular}{llll} 
Variables & OR & Cl & p-value \\
\hline BMI & 0.94 & $0.84-1.04$ & 0.24 \\
\hline MAC & 0.95 & $0.83-1.08$ & 0.42 \\
\hline TSFt & 0.99 & $0.94-1.05$ & 0.93 \\
\hline MAMC & 0.94 & $0.81-1.09$ & 0.43 \\
\hline APMt & 1.01 & $0.92-1.10$ & 0.74 \\
\hline PhA & 1.02 & $0.65-1.62$ & 0.90 \\
\hline BCM & 0.92 & $0.87-0.97$ & $<0.01$ \\
\hline
\end{tabular}

Logistic regression: Data adjusted by sex, age, ingested calories and CRP; OR: odds ratio; $\mathrm{Cl}$ : $95 \%$ confidence interval; BMI: body mass index; MAC: mid-arm circumference; TSFt: triceps skin fold thickness; MAMC: mid-arm muscle circumference; APMt: adductor pollicis muscle thickness; BCM: body cell mass; PhA: phase angle.

testinal tract and its effects on food intake and absorption. ${ }^{4,22-24}$ Malnutrition is especially common in active UC patients after long-term hospitalization; ${ }^{11,25}$ however, few studies have evaluated the nutritional status in patients

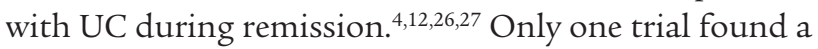
more compromised nutritional status (body weight and $\mathrm{BMI}$ ) in UC patients during remission than in a control group. ${ }^{28}$ In our study, we identified a low incidence of calorie malnutrition. Most patients had normal levels of fat mass and muscle mass, according to the MAC and TSFt parameters, respectively. Besides, $56 \%$ were overweight/ obese, according to BMI. The low rate of underweight identified (3.4\%) can be partly explained by the remission status of patients, and confirms data shown by other authors. ${ }^{11,12,28}$ Most of the patients presented distal colitis in our study; this is not reflective of the general UC population and can be explained by the exclusion of those with moderate-severe disease.

BIA is a method frequently used for body composition measurements and offers advantages such as simplicity, portability, cost and absence of radiation exposure. ${ }^{29} \mathrm{It}$ is known that PhA and body cell mass (BCM) are good prognosis indicators in several clinical situations. ${ }^{12,21,30,31}$ Although the biological meaning is not completely understood, PhA is applied as a surrogate marker for quality of lean body mass ${ }^{32}$ and is considered a marker of cell health since high $\mathrm{PhA}$ values reflect a strong cell function. ${ }^{33}$ Previous studies have shown an association between low values of $\mathrm{PhA}$ and BCM with prognosis worsening in patients with hepatitis $\mathrm{C}$ and hemodialysis patients. ${ }^{30,34}$ However, few studies have approached PhA and BCM in UC. ${ }^{12,32}$ It is important to emphasize that the gold standard method for assessing body composition is dual-energy $\mathrm{X}$-ray absorptiometry (DEXA), which allows direct and non-invasive measurement of bone mass, fat-free mass and fat mass. However, DEXA requires skilled personnel, has low affordability, high radiation exposure and is considered a costly examination. ${ }^{35,36}$ In addition, studies show good correlation between the parameters of body composition assessed using either BIA or DEXA. ${ }^{37}$

Our study showed that anthropometric and biochemical parameters were correlated with $\mathrm{PhA}$. The lean body mass anthropometric variable (MAMC) currently correlated with $\mathrm{PhA}$ has been reported in hemodialysis patients. ${ }^{34}$ A direct association between $\mathrm{PhA}$ and lean body mass parameter has also been suggested by the positive correlation found between grip strength and PhA in IBD children with mild activity. ${ }^{32}$ In addition to the anthropometric indicators, Pearson's correlation analysis revealed that PhA presented inverse correlation with inflammatory markers such as CRP and ESR and direct correlation with hemoglobin, although these markers were in the normal range. Modest CRP changes have been observed in the active $\mathrm{UC}^{38}$ and the utility of $\alpha 1$-acid glycoprotein, $\mathrm{ESR}^{39}$ and hemoglobin have been questioned in UC. The lack of studies analyzing the relation between $\mathrm{PhA}$ and those markers in UC patients prevents further comparisons.

In the present study, we found that lean mass was inversely correlated with the non-specific inflammation marker (APMt vs. ESR) and directly correlated with hemoglobin values (MAMC vs. hemoglobin). The results indicate a role of inflammatory reactants in the body composition of UC patients. There are few studies evaluating body composition in UC patients ${ }^{12,28,39-41}$ and some of them ${ }^{12,40}$ included inflammatory variables in the analysis. Examining inactive UC patients, absence of associations was found between inflammatory and body composition variables in two studies ${ }^{40,42}$ and decreased BCM in subjects with supranormal CRP values $(\geq 8 \mathrm{mg} / \mathrm{dL})$ was identified in one. ${ }^{12}$

The inverse correlation found between $\alpha 1$-acid glycoprotein and remission time has not been reported in UC patients. High serum concentration of $\alpha 1$-acid glycoprotein was associated with high susceptibility to induce colitis in rodents ${ }^{43}$ and positively correlated with the risk of relapse in UC patients. ${ }^{44}$

Although the acute phase protein, CRP, has been positively correlated with IBD activity, ${ }^{10}$ its association with disease extent in UC patients in clinical remission was presently identified. Remission time was lower in patients with pancolitis (12 months) compared to those with distal colitis ( 24 months). Therefore higher CRP levels were found in this group. Even though CRP short half-life of 19 h could not support such explanation, a recent study showed that a mean CRP levels of $5.4 \mathrm{mg} / \mathrm{L}$ 
(normal range) was associated with high histological inflammation scores in patients with ulcerative colitis during clinical remission. ${ }^{45}$ Such results raise awareness to the fact that patients in clinical remission from UC still may have inflammation.

It is valid to evaluate the inflammatory profile of IBD patients, even in clinical remission. But it is important to bear in mind that the classification of the disease activity was based on clinical criteria (Truelove and Witts $\left.{ }^{13}\right)$. The best classification of clinical remission is based on a combination of clinical parameters (stool frequency $\leq 3 /$ day with no bleeding) and absence of mucosal lesions at endoscopy. ${ }^{46}$ This was not performed in our study, which is a limitation. Because of that, patients could be classified as clinical remission and still present active inflammatory process with changes in inflammatory markers and intestinal inflammation. Besides, inflammatory markers such as CRP and ESR are not specific $^{47}$ and may not reflect the intestinal inflammation accurately. On the other hand, fecal markers such as calprotectin and lactoferrin can be considered accurate markers of colonic inflammation. ${ }^{47}$

We also evaluated possible associations between disease extent and body composition variables. High BCM levels were associated with better prognosis and quality of life ${ }^{12,31}$ and low BCM levels were associated with supranormal CRP values in UC patients, ${ }^{12}$ but studies approaching $\mathrm{BCM}$ and disease extent are lacking. After adjustment for confounders (energy, gender, age and CRP), logistic regression analysis revealed that body cell mass was associated with extension of the disease. BCM is a marker for combined visceral and somatic protein deposits. It represents the most metabolically active compartment of the body and catabolic conditions may lead to its reduction. ${ }^{17}$ It is plausible that more extensive UC is associated with less protein deposits, as seen in other diseases, ${ }^{45}$ and/ or related with high catabolic conditions. ${ }^{17}$ Considering the results found in our population we might suggest that patients with better lean body mass had a lower susceptibility to the development of more extensive injury.

It is important to emphasize that these patients cannot be considered representative of the population of ulcerative colitis, since they derive from a hospital for individuals in the range of low income and low education. UC disease activity was assessed based on Truelove and Witts criteria, although the Mayo score is preferable. No endoscopic data were available at the time of the study to ascertain disease activity, and disease remission was based on clinical aspects. We do not have fecal calprotectin test available. Other limiting factors should also be mentioned, namely sample size and study design (cross-sectional), as well as the absence of a control group for comparison.

In spite of the limitations above, the outcomes of our study contribute for the expansion of knowledge about the associations of body composition, inflammatory status and disease extension in clinical remission or mild disease activity in patients with ulcerative colitis. These findings are of great importance for clinical practice, since bioelectrical impedance analysis can be considered a simple examination, noninvasive and rapidly implemented. Additionally, the results indicate that some factors could be modified to prevent inflammation and extension of ulcerative colitis. The factors deserving attention include free fat and body cell masses.

\section{Conclusion}

Patients with ulcerative colitis in clinical remission do not present impairment of nutritional status according to BMI and BIA parameters. There were associations between body composition, inflammatory profile and disease extent; acute inflammatory markers were inversely correlated with phase angle, duration of remission and directly correlated with fat mass anthropometric indicators and also disease extent. Furthermore, body cell mass was associated with disease extent.

\section{AcKnowledgments}

We thank the São Paulo Research Foundation (FAPESP) (grant \# 2009/03449-3 [Master's Scholarship] and grant \#2007/07455-2 [Research Financial Support]) and Research Support Group at São Paulo State University (Unesp), Medical School, Botucatu, which helped with the statistical analysis.

\section{Conflict of interest}

The authors declare no conflict of interest.

\section{Resumo}

Associações entre composição corporal, perfil inflamatório e extensão da doença em pacientes com retocolite ulcerativa

Objetivo: Avaliar a composição corporal de pacientes portadores de retocolite ulcerativa em remissão clínica e sua associação com o perfil inflamatório e a extensão da lesão intestinal.

Método: Foi realizado um estudo transversal. Os dados relacionados à composição corporal foram ângulo de fase (AF), massa adiposa (MA), dobra cutânea triciptal (DCT), circunferência do braço (CB), circunferência muscular do 
braço (CMB) e espessura do músculo adutor do polegar (EMAP). O perfil inflamatório foi avaliado através da dosagem da proteína-C reativa (PCR), $\alpha 1$-glicoproteína ácida e velocidade de hemossedimentação (VHS) e a extensão da doença foi avaliada de acordo com o exame endoscópico. Resultados: Foram avaliados 59 pacientes. A média de idade foi de 48,1 anos e 53,3\% eram mulheres. A maioria dos pacientes $(94,9 \%)$ estava em remissão clínica da doença e 3,4\% foi classificada como desnutrida de acordo com o IMC. Observou-se uma correlação inversa entre AF e marcadores inflamatórios como a PCR $(\mathrm{R}=-0,59 ; \mathrm{p}<0,001)$ e VHS $(R=-0,46 ; p<0,001)$ e uma correlação direta entre AF e os indicadores de massa magra como $\mathrm{CMB}(\mathrm{R}=0,31$; $\mathrm{p}=0,01)$ e $\operatorname{EMAP}(\mathrm{R}=0,47 ; \mathrm{p}<0,001)$. A massa magra foi inversamente correlacionada com marcadores inflamatórios não específicos, como a VHS, e diretamente correlacionada com a hemoglobina. De acordo com a análise de regressão logística, a massa celular corporal foi associada com extensão da lesão intestinal (OR 0,92; IC95\% 0,87-0,97; p<0,01). Conclusão: AF foi inversamente correlacionado com marcadores inflamatórios e diretamente correlacionado com a massa magra. Marcadores inflamatórios de fase aguda e massa celular corporal foram correlacionados com extensão da lesão intestinal.

Palavras-chave: Composição Corporal. Colite Ulcerativa. Proteína C-Reativa. Biomarcadores. Índice de Gravidade de Doença.

\section{RefEREnCES}

1. Mowat C, Cole A, Windsor A, Ahmad T, Arnott I, Driscoll R, et al. Guidelines for the management of inflammatory bowel disease in adults. Gut. 2011; 60(5):571-607.

2. Gaburri PD, Chebli JM, Castro LE, Ferreira JO, Lopes MH, Ribeiro AM, et al. [Epidemiology, clinical features and clinical course of Crohn's disease: a study of 60 cases]. Arq Gastroenterol. 1998; 35(4):240-6.

3. Souza MH, Troncon LE, Rodrigues CM, Viana CF, Onofre PH, Monteiro RA, et al. [Trends in the occurrence (1980-1999) and clinical features of Crohn's disease and ulcerative colitis in a university hospital in Southeastern Brazil]. Arq Gastroenterol. 2002; 39(2):98-105.

4. Elia PP, Fogaça HS, Barros RG, Zaltman C, Elia CS. [Descriptive analysis of the social, clinical, laboratorial and anthropometric profiles of inflammatory bowel disease inwards patients from the "Clementino Fraga Filho" University Hospital, Rio de Janeiro, RJ, Brazil]. Arq Gastroenterol. 2007; 44(4):332-9.

5. Cosnes J, Gower-Rousseau C, Seksik P, Cortot A. Epidemiology and natural history of inflammatory bowel diseases. Gastroenterology. 2011; 140(6):1785-94.

6. Victoria CR, Sassaki LY, Nunes HRC. Incidence and prevalence rates of inflammatory bowel diseases, in Midwestern of São Paulo State, Brazil. Arq Gastroenterol. 2009; 46(1):20-5.

7. Wild GE, Drozdowski L, Tartaglia C, Clandinin MT, Thomson AB. Nutritional modulation of the inflammatory response in inflammatory bowel disease: from the molecular to the integrative to the clinical. World J Gastroenterol. 2007; 13(1):1-7.

8. Cho JH, Brant SR. Recent insights into the genetics of inflammatory bowel disease. Gastroenterology. 2011; 140(6):1704-12.

9. Masoodi I, Kochhar R, Dutta U, Vaishnavi C, Prasad KK, Vaiphei K, et al. Fecal lactoferrin, myeloperoxidase and serum $\mathrm{C}$-reactive are effective biomarkers in the assessment of disease activity and severity in patients with idiopathic ulcerative colitis. J Gastroenterol Hepatol. 2009; 24(11):1768-74.

10. Lewis JD. The utility of biomarkers in the diagnosis and therapy of inflammatory bowel disease. Gastroenterology. 2011; 140(6):1817-26.

11. Rocha R, Santana GO, Almeida N, Lyra AC. Analysis of fat and muscle mass in patients with inflammatory bowel disease during remission and active phase. Br J Nutr. 2009; 101(5):676-9.

12. Valentini L, Schaper L, Buning C, Hengstermann S, Koernicke T, Tillinger W, et al. Malnutrition and impaired muscle strength in patients with Crohn's disease and ulcerative colitis in remission. Nutrition. 2008; 24(7-8):694-702.

13. Truelove SC, Witts LJ. Cortisone in ulcerative colitis: final report on a therapeutic trial. Br Med J. 1955; 2(4947):1041-8.

14. World Health Organization. Obesity: preventing and managing the global epidemic. Report on a WHO consultation (WHO Publication WHO/NUT/ NCD/98.1). Geneva: World Health Organization; 1997.

15. Callaway CW, Chumlea WC, Bouchard C, Himes JH, Lohman TG, Martin AD. Circumferences. In: Lohman TG, Roche AF, Martorell R, editors. Anthropometric standardizing reference manual. Champaign: Human Kinetics Books; 1991. p. 39-54.

16. Harrison GG, Buskirk EK, Carter JEL, Ohmston JFE, Lohman TG, Pollock ML. Skinfold thicknesses and measurements technique. In: Lohman TG, Roche AF, Martorell R, eds. Anthropometric standardizing reference manual. Champaign: Human Kinetics Books; 1991. p. 55-80.

17. Frisancho AR. Anthropometric standards for the assessment of growth and nutritional status. Michigan: The University of Michigan Press; 1990.

18. Andrade FN, Lameu EB, Luiz RR. Musculatura adutora do polegar: um novo índice prognóstico em cirurgia cardíaca valvar. Rev SOCERJ. 2005; 18(5):384-91.

19. Lipschitz DA. Screening for nutritional status in the elderly. Prim Care. 1994; 21(1):55-67.

20. Frisancho AR. New standards of weight and body composition by frame size and height for assessment of nutritional status of adults and the elderly. Am J Clin Nutr. 1984; 40(4):808-19.

21. Kyle UG, Bosaeus I, De Lorenzo AD, Deurenberg P, Elia M, Manuel Gómez $\mathrm{J}$, et al. Bioelectrical impedance analysis-part II: utilization in clinical practice. Clin Nutr. 2004; 23(6):1430-53.

22. Weisshof R, Chermesh I. Micronutrient deficiencies in inflammatory bowel disease. Curr Opin Clin Nutr Metab Care. 2015; 18(6):576-81.

23. Csontos ÁA, Molnár A, Piri Z, Pálfi E, Miheller P. Malnutrition risk questionnaire combined with body composition measurement in malnutrition screening in inflammatory bowel disease. Rev Esp Enferm Dig. 2017; 109(1):26-32.

24. Thangarajah D, Hyde MJ, Konteti VK, Santhakumaran S, Frost G, Fell JM. Systematic review: body composition in children with inflammatory bowel disease. Aliment Pharmacol Ther. 2015; 42(2):142-57.

25. Geerling BJ, Badart-Smook A, Stockbrugger RW, Brummer RJ. Comprehensive nutritional status in recently diagnosed patients with inflammatory bowel disease compared with population controls. Eur J Clin Nutr. 2000; 54(6):514-21.

26. Ulivieri FM, Piodi LP, Taioli E, Lisciandrano D, Ranzi T, Vezzoli M, et al. Bone mineral density and body composition in ulcerative colitis: a six-year follow-up. Osteoporos Int. 2001; 12(5):343-8.

27. Ripoli J, Miszputen SJ, Ambrogini Jr O, Carvalho L. Nutritional follow-up of patients with ulcerative colitis during periods of intestinal inflammatory activity and remission. Arq Gastroenterol. 2010; 47(1):49-55.

28. Jahnsen J, Falch JA, Mowinckel P, Aadland E. Body composition in patients with inflammatory bowel disease: a population-based study. Am J Gastroenterol. 2003; 98(7):1556-62.

29. Ling CH, de Craen AJ, Slagboom PE, Gunn DA, Stokkel MP, Westendorp RG, et al. Accuracy of direct segmental multi-frequency bioimpedance analysis in the assessment of total body and segmental body composition in middle-aged adult population. Clin Nutr. 2011; 30(5):610-5.

30. Kahraman A, Hilsenbeck J, Nyga M, Ertle J, Wree A, Plauth M, et al. Bioelectrical impedance analysis in clinical practice: implications for hepatitis C therapy BIA and hepatitis C. Virol J. 2010; 7:191.

31. Werkstetter KJ, Ullrich J, Schatz SB, Prell C, Koletzko B, Koletzko S. Lean body mass, physical activity and quality of life in paediatric patients with inflammatory bowel disease and in healthy controls. J Crohns Colitis. 2012; 6(6):665-73.

32. Kyle UG, Soundar EP, Genton L, Pichard C. Can phase angle determined by bioelectrical impedance analysis assess nutritional risk? A comparison between healthy and hospitalized subjects. Clin Nutr. 2012; 31(6):875-81.

33. Wirth R, Volkert D, Rösler A, Sieber CC, Bauer JM. Bioelectric impedance phase angle is associated with hospital mortality of geriatric patients. Arch Gerontol Geriatr. 2010; 51(3):290-4. 
34. Oliveira CM, Kubrusly M, Mota RS, Silva CA, Choukroun G, Oliveira VN. The phase angle and mass body cell as markers of nutritional status in hemodialysis patients. J Ren Nutr. 2010; 20(5):314-20.

35. Haderslev KV, Haderslev PH, Staun M. Accuracy of body composition measurements by dual energy X-ray absorptiometry in underweight patients with chronic intestinal disease and in lean subjects. Dyn Med. 2005; 4(1):1.

36. Kohrt WM. Preliminary evidence that DEXA provides accurate assessment of body composition. J Appl Physiol. 1998; 84(1):372-7.

37. Thibault R, Genton L, Pichard C. Body composition: why, when and for who? Clin Nutr. 2012; 31(4):435-47.

38. Vilela EG, Torres HO, Martins FP, Ferrari ML, Andrade MM, Cunha AS Evaluation of inflammatory activity in Crohn's disease and ulcerative colitis. World J Gastroenterol. 2012; 18(9):872-81.

39. Capristo E, Mingrone G, Addolorato G, Greco AV, Gasbarrini G. Metabolic features of inflammatory bowel disease in a remission phase of the disease activity. J Inter Med. 1998; 243(5):339-47.

40. Capristo E, De Gaetano A, Mingrone G, Addolorato G, Greco AV, Castagneto $\mathrm{M}$, et al. Multivariate identification of metabolic features in inflammatory bowel disease. Metabolism. 1999; 48(8):952-6.

41. Capristo E, Mingrone G, Addolorato G, Greco AV, Gasbarrini G. Glucose metabolism and insulin sensitivity in inactive inflammatory bowel disease. Aliment Pharmacol Ther. 1999; 13(2):209-17.
42. Reimund JM, Arondel Y, Escalin G, Finck G, Baumann R, Duclos B. Immune activation and nutritional status in adult Crohn's disease patients. Dig Liver Dis. 2005 ; 37(6):424-31

43. Hochepied T, Wullaert A, Berger FG, Baumann H, Brouckaert P, Steidler L, et al. Overexpression of $\alpha 1$-acid glycoprotein in transgenic mice leads to sensitisation to acute colitis. Gut. 2002; 51(3):398-404

44. Vermeire S, Van Assche G, Rutgeerts P. Laboratory markers in IBD: useful, magic, or unnecessary toys? Gut. 2006; 55(3):426-31.

45. Rosenberg L, Nanda KS, Zenlea T, Gifford A, Lawlor GO, Falchuk KR, et al. Histologic markers of inflammation in patients with ulcerative colitis in clinical remission. Clin Gastroenterol Hepatol. 2013; 11(8):991-6.

46. Travis SP, Dinesen L. Remission in trials of ulcerative colitis: what does it mean? Pract Gastroenterol. 2010; 30:17-20.

47. Magro F, Gionchetti P, Eliakim R, Ardizzone S, Armuzzi A, Barreiro-de Acosta M, et al. Third European Evidence-based Consensus on Diagnosis and Management of Ulcerative Colitis. Part 1: definitions, diagnosis, extraintestinal manifestations, pregnancy, cancer surveillance, surgery, and ileoanal pouch disorders. J Crohns Colitis. 2017; 11(6):649-70. 